\title{
二次元加速度計測信号の複素スペクトル解析とその応用 加速度ベクトルの時間変化に関する定量的比較評価法
}

\author{
山 本 広 樹*.青 島 伸 治** \\ Complex Spectrum Analysis of Two Dimensional Acceleration Data and Its Application \\ Quantitative Comparison and Evaluation of Time Trace of Acceleration Vector ${ }^{\dagger}$
}

Hiroki Yamamoto* and Nobuharu Aoshima**

\begin{abstract}
Dealing with two dimensional acceleration signal as a complex signal on Gaussian plane, the time characteristics of the acceleration vector can be analyzed by Fourier transform on complex form. The spectrum calculated with this method is useful to understand the physical image of two dimensional movements about the acceleration. Therefore, for the quantitative comparison and evaluation of the behavior of two dimensional acceleration data, some evaluate functions and index parameters based on the complex spectrum are proposed. And analyses of vehicle crash acceleration data are described to show the effectiveness.
\end{abstract}

Key Words: acceleration measurement, complex signal processing, Fourier transform, spectral analysis

\section{1. 緒言}

加速度計測により物体の運動解析や相互作用力の推定を行 なうとき，その計測值を波形として直接観察するだけでなく 定量的に比較評価したいことがある。こうした場合，フーリ エ変換による周波数スペクトル分析は, 加速度の時間的変化 をとらえるのに効果的な手法の一つである.

一方, 二軸の加速度センサを用いて計測を行なうと 2 自由 度の加速度計測信号が得られる.ところが，このような二次 元の加速度計測信号に対してスペクトル分析を行なう場合, 各軸成分単体で観察したり，あるいは加速度べクトルの大き さや向きといった一次元で観察できる信号に変換した後処理 を行なうことが多い.

本研究の目的は, 二次元の加速度計測信号をそのまま一つ の複素信号として処理することにより，計測信号の特徵をべ クトル量の時間変化として捉えることが可能な解析方法を得 ることにある。

そこで, 複素スペタトルを基に, 加速度デー夕の定量的な 比較に向く評価指標を提案するとともに，自動車の衝突加速 度デー夕に対する評価例からその有効性を示した。

†第 40 回 SICE 学術講演会にて発表 $(2001 \cdot 7)$

* 筑波大学大学院工学研究科 つくば市天王台 1-1

** 筑波大学 つくば市天王台 $1-1$

* Doctoral Program in Engineering, University of Tsukuba, Tsukuba

** University of Tsukuba, Tsukuba

(Received April 16, 2001)

(Revised July 6, 2001)

\section{2. 加速度計測值の複素表現}

物体に固定された二軸加速度センサの時刻 $t$ における $X$ 軸 および $Y$ 軸成分の計測信号出力をおのおの $x_{a}(t), y_{a}(t)$ とす る.すなわち $x_{a}(t), y_{a}(t)$ は物体に固定された直交座標 $X Y$ で観察される瞬間加速度べクトルの $X$ 軸成分と $Y$ 軸成分であ る。ただし，物体の運動は計測面と平行な平面内に拘束され ているものとする.

このような加速度計測信号に対し，普通は各軸成分につい て個々に分析したり，極座標表示に変換することにより大き さや向きの変化に置き直して定量的な解析を行なっている. ところが時間に対する加速度べクトルの二次元的振る舞いに ついては, 前述の解析值やリサージュ波形の特徵を基にした 観察者による判断が主体であった.

そこで, 観測座標として用いている直交座標 $X Y$ の座標軸 $Y$ を便宜上虚数軸と考えることにより，計測面をガウス平面 と見なし，加速度信号を，

$$
c_{a}(t)=x_{a}(t)+j \cdot y_{a}(t)
$$

なる複素信号として扱う。このように複素表現を用い狄ば， 2 次元のベクトル量としての加速度を一つの量として取り扱 うことができる，その結果, 評価システムの実装時に解析処 理の見通しが良くなる。 また，各軸ごとにフーリエ変換を行 なう場合と比較して，フーリ工変換処理が 1 度で済み，処理 装置内の信号の流れも単純になる。

\section{3. 複素スペクトルの解釈}

加速度信号を複素表現に変換することにより, 複素フーリ 
エ変換によるスペクトル解析を適用することができる．ここ ではその処理結果であるスペクトルについて，その物理的意 味を考える。

複素フーリエスペクトルは複素フーリエ係数の值をその周 波数にしたがって並べたものであり，周波数 ににおける值は，

$$
C_{a}(\nu)=\int_{-\infty}^{+\infty} c_{a}(t) \cdot e^{-j 2 \pi \nu t} d t
$$

として求められる．また，フーリエ係数全体すなわちスペク トルと元の信号との関係は, 時間領域においてつぎの逆フー リエ変換で表わすことができる.

$$
c_{a}(t)=\frac{1}{2 \pi} \int_{-\infty}^{+\infty} C_{a}(\nu) \cdot e^{j 2 \pi \nu t} d \nu
$$

実際の解析では，有限時間の計測信号について $\mathrm{AD}$ 変換を行 ない計算機処理するため, 加速度信号 $c_{a}(t)$ を標本化間隔 $\delta t$ の離散時間時系列信号として扱う。そこで Eq.(3)は, デー夕 数を時刻 $t=0$ を中心に $2 N$ 個として，

$$
c_{a}(t)=\frac{1}{2 N} \sum_{k=-N}^{N-1} C_{a}\left(\frac{k}{\delta t N}\right) \cdot e^{j \frac{k}{\delta t N} t}
$$

となる。ここでガウス平面上に於ける $e^{j \alpha t}$ の振る舞いにつ いて考えてみると, 原点を中心として一定角速度 $\alpha \mathrm{rad} / \mathrm{s}$ で円軌道を描く回転べクトルであると解釈できる。ただし， Eq.(3)では $\alpha=2 \pi \nu$, Eq.(4)では $\alpha=\frac{k}{\delta t N}$ である.すなわ ち, Eq.(4)は, ガウス平面上での複雑な加速度ベクトルの動 きを，単純な定速円運動べクトルの和の形に分解するものと 考えることができる.つまりこのとき得られる複素スペクト ルの振幅值は分解された円運動の半径を, 位相は時刻 $t=0$ での円軌道上の位置（ベクトルの向き）を意味する。また， 周波数 の周波数は回転方向が逆であることを意味すると解釈できる. さらに，加速度ベクトルを時間全体で観察する，すなわちガ ウス平面上の加速度べクトルが描く軌跡としてとらえる場合 には，Eq.(4) は複雑な加速度べクトルの軌跡である曲線を円 軌跡に分解しているとも解釈できる。これを図解したものが Fig. 1 である.

このように，高い周波数に振幅スペクトルのピークが存在 するということは，加速度べクトルの動きに短い周期でかつ 大きな動きの成分が含まれていることを示唆している，逆に 低い周波数にピークがあ机ば，長い周期の大きな動きを含む ことを意味する．また, 周波数 $\nu=0$ での值は, 平均加速度 を示しているとともに, ベクトルの描く軌跡の座標原点から のオフセットを表わしている.

すなわち，複素表現された加速度信号に対し複素フーリエ 変換を行なうことにより，加速度の時間的変化をべクトルと して一体的にとらえることができる。また，複素スペクトル は数值で得られるため, デー夕数の違いを補償する処理を行 なうことにより，個々の計測デー夕について定量的な比較を 行なうことが可能となるものと考えられる。

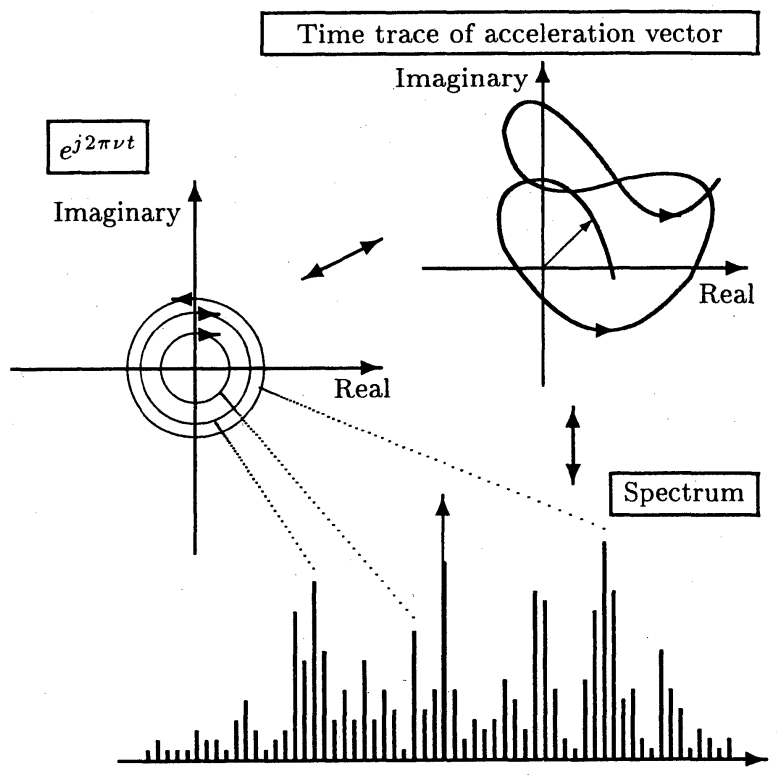

Frequency

Fig. 1 Geometric image of a complex Fourier spectrum

\section{4. 複素スペクトルを基にした評価指標}

二次元加速度計測信号を複素表現することによって得られ る複素スペクトルは，必ずしも原点対称とはならない。そ こで, 加速度ベクトルのある周期的な動き mov. $(T)$ の成分 $(T \neq 0)$ を，その正負の周波数 $\pm \nu= \pm 1 / T$ に対応するスぺ クトル值の組（和）により考える。

$$
\operatorname{mov} .(T)=C_{a}\left(\frac{1}{T}\right) \cdot e^{j \frac{2 \pi}{T} t}+C_{a}\left(\frac{-1}{T}\right) \cdot e^{-j \frac{2 \pi}{T} t}
$$

この式によって表わされるべクトル軌跡は，周期 $T$ 成分のリ サージュ波形に相当し，幾何学的には原点対称な棈円ないし 線分または真円となる。ここで，周期 Tの動きに対応する正 負の周波数士 $\nu$ における複素スペクトルを，各々振幅 $r_{p}, r_{n}$, 位相 $\phi_{p}, \phi_{n}$ として,

$$
\left\{\begin{array}{l}
C_{a}(\nu)=r_{p} e^{j \phi_{p}} \\
C_{a}(-\nu)=r_{n} e^{j \phi_{n}}
\end{array}\right.
$$

と置けば, ベクトル軌跡の形態はつぎのように分類できる。

(1) $r_{p} \neq r_{n} \neq 0$ の場合

この場合には，Eq.(5)で表わされるべクトルの軌跡は 原点対称な棈円軌道となる. 長半径は $r_{p}+r_{n}$, 短半径は $\left|r_{p}-r_{n}\right|$ に, 傾き $\phi$ は $\frac{\phi_{p}+\phi_{n}}{2}$ となる. ベクトルの回転方 向は $r_{p}-r_{n}$ の符号で示される.

ただし，反時計回りを正回転とし，位相の值域は士 \pm と する (以下同様)．また，傾きは長半径が実数軸となす角度 をラジアンで表わすものとする.

(2) $r_{p}=r_{n} \neq 0$ の場合

この場合には, Eq.(5)で表わされるべクトルの軌跡は原

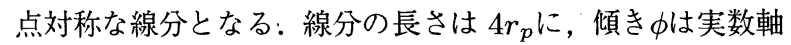
に対して $\frac{\phi_{p}+\phi_{n}}{2}$ となる. 

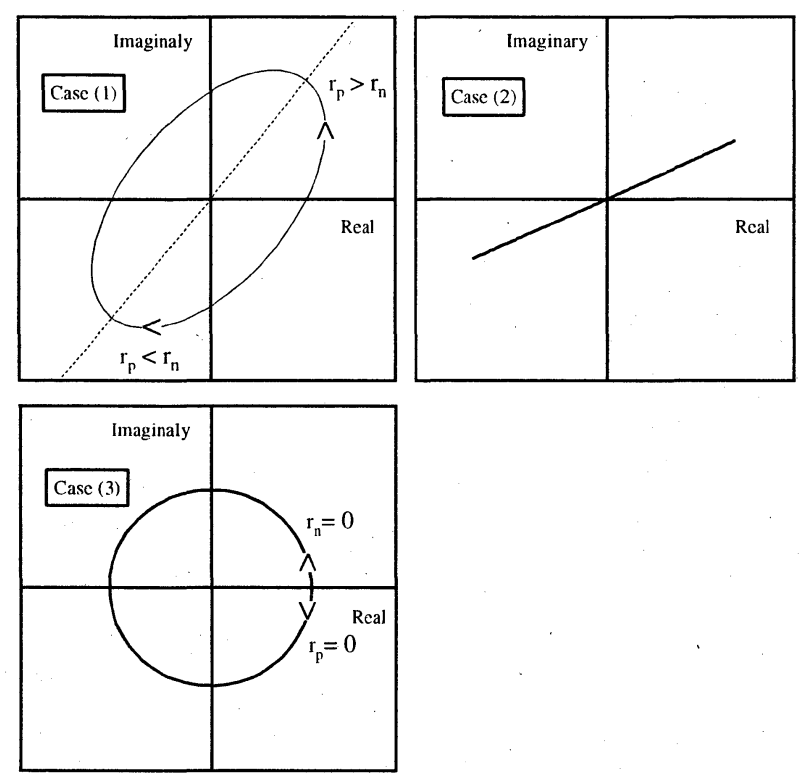

Fig. 2 Time trace variation of mov. $(t)$

\section{( 3 ） $r_{p}=0$ または $r_{n}=0$ の場合}

この場合には，周期 $T$ の動きは $C_{a}(-\nu) \cdot e^{-j 2 \pi \nu t}$ ないし $C_{a}(\nu) \cdot e^{j 2 \pi \nu t}$ となり, ベクトルの軌跡は原点を中心とする 半径 $r_{n}$ ないし $r_{p}$ の真円軌道となる。 なお， $r_{p}=r_{n}=0$ の場合には当然ながらべクトルの大きさが常に 0 となるた め, 軌跡は描かれない. Fig. 2 に軌道の例を示す.

このように, 複素スペクトルの值から加速度ベクトルの時 間的変化が二次元的な広がりをもつ動きであるかどうかを判 断することができる．たとえば正負の周波数において振幅ス ペクトルが等しい場合は，たとえその值が大きくても線分上 の一次元的な運動であることがわかる。

そこで，複素フーリエ変換によって得られたスペクトル デー夕を基に周期 $T$ を変数とするつぎのような評価関数 $\operatorname{Activity}(T), \operatorname{Aspect.r}(T), \operatorname{Atitude}(T)$ を考える.

$$
\begin{aligned}
\operatorname{Activity}(T) & =A(T) \cdot A^{\prime}(T) \\
\text { Aspect.r }(T) & =\frac{\left|A^{\prime}(T)\right|}{A(T)} \\
A(T) & =\left|C_{a}\left(\frac{1}{T}\right)\right|+\left|C_{a}\left(-\frac{1}{T}\right)\right| \\
A^{\prime}(T) & =\left|C_{a}\left(\frac{1}{T}\right)\right|-\left|C_{a}\left(-\frac{1}{T}\right)\right| \\
\operatorname{Atitude}(T) & =\frac{\arg \left(C_{a}\left(\frac{1}{T}\right)\right)+\arg \left(C_{a}\left(-\frac{1}{T}\right)\right)}{2}
\end{aligned}
$$

するとその式の形からわかるように, Activity $(T)$ が軌道の 大きさの目安となり, Aspect.r $(T)$ が軌道のアスペクト比に 相当し, $\operatorname{Atitude}(T)$ が軌道の傾きを示している.すなわち, これらの評価関数は加速度ベクトルの二次元的な動きの大き さや傾向を比較考察する指標となる。なお，Aspect.r $(T)$ は 0〜1の值をとり，0のときは線分，1のときは真円軌道，そ の他の場合は楕円軌道であることを示す.

また, Eq.(7)で得られる評価関数の値について，周期 $T に$
関する積分值やグラフの図心を求めることにより, 一つの数 值として加速度べクトルの二次元的な時間変化の特徵を示唆 する定量的な指標を得ることもできる。

こうした評価関数の組み合わせにより，複数の加速度デー 夕を定量的に比較評価できると考えられる。なお，具体的な 計算例については後述する。

\section{5. 衝擊加速度の解析に対する適用例}

近年, 自動車事故の解析を目的とした車載型の計測記録装 置について世界中で研究開発が進められている ${ }^{1), 2), 4) 。 こ の ~}$ ような装置は，事故の検出と記録を目的として加速度センサ を備えており，中には製造コストなどのバランスから 2 軸の 加速度計測記録能力を備えた製品がある。ここでは，本方法 の有効性について検討するため，具体的な応用例の一つとし て事故記録装置から得ら机る2次元衝撃加速度デー夕の複素 スペクトルによる評価について述べる.

\section{1 計測モデル}

Fig. 3 のように直交する $2 つ の$ 計測軸 $x, y$ を持った加速度 センサを車体の重心へ水平に固定した車両モデルを考える. 時刻 $t$ における前後加速度計測值を車両の前方向を正にとり $a x(t)$, 左右加速度計測值を左方向を正にとり $a y(t)$ とする。 なお，車両モデルを剛体とし，質量変化を無視して水平面 (計測平面) 内に拘束された運動を考えれば，各時刻におい て車両に作用する外力の総和は加速度計測値 $a x(t), a y(t)$ に 車両の質量を乗じることにより推定することができる．たた し，これらの計測值は車体に固定された座標系で表示されて いることに注意が必要である。すなわち，速度や運動軌跡な どの車両挙動をこの加速度計測値の積分から求めようとする 場合には, 地上に固定した座標系での表示に変換しなけ札ば ならない，その場合，各時刻における車両の向きも知る必要 がある ${ }^{3)}$

\section{2 解析方法}

加速度計測信号 $a x(t), a y(t)$ は Eq.(1) を用いて複素表現 $c_{a}(t)$ に変換し, 複素離散フーリ工変換を行なってそのスペ クトルを求める. 実際の計算処理には市販のデータ解析ソフ トを用いた。なお，比較のために，実数である各軸成分ごと の加速度信号についても離散フーリエ変換を行ないその振幅 スペクトルを求めた。また， 2 軸の加速度計測值を極座標表 示に変換することによって加速度の大きさと方向に変換した データについても振幅スペクトルを求めた.

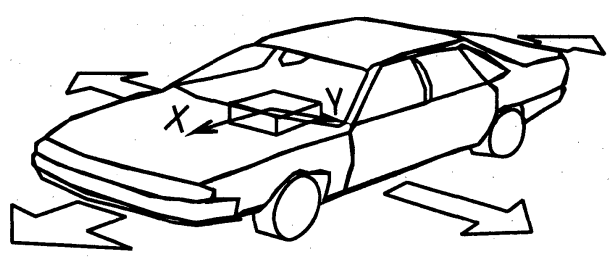

Fig. 3 Device model fixed on the vehicle 


\section{3 使用データ}

サンプルデータとして Fig. 4 に自動車対自転車の衝突事故 に扔ける衝撃加速度デー夕を示す．実線は前後方向の加速度 $a x(t)$ を，破線は横方向の加速度 $a y(t)$ を示している.なお，

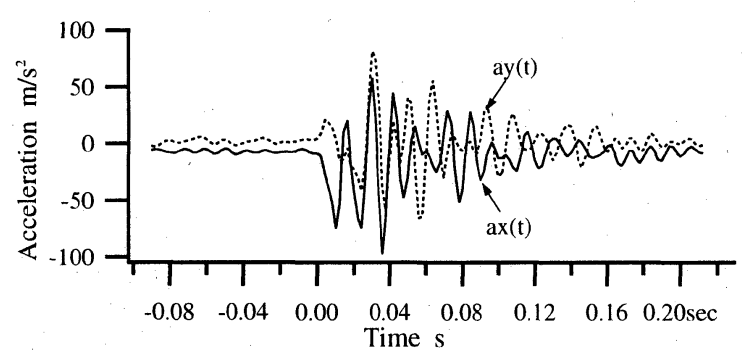

Fig. 4 Acceleration data at a collision
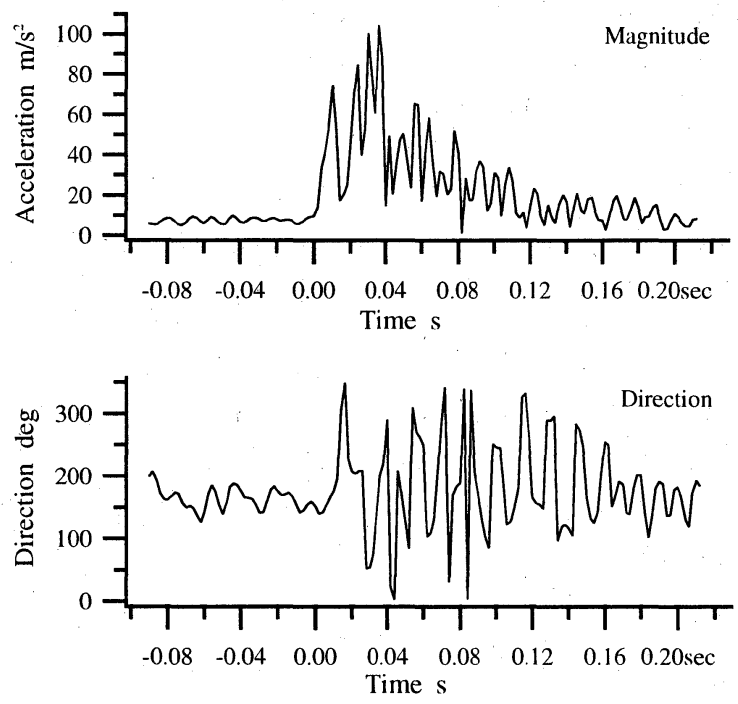

Fig. 5 Magnitude and direction of the acceleration

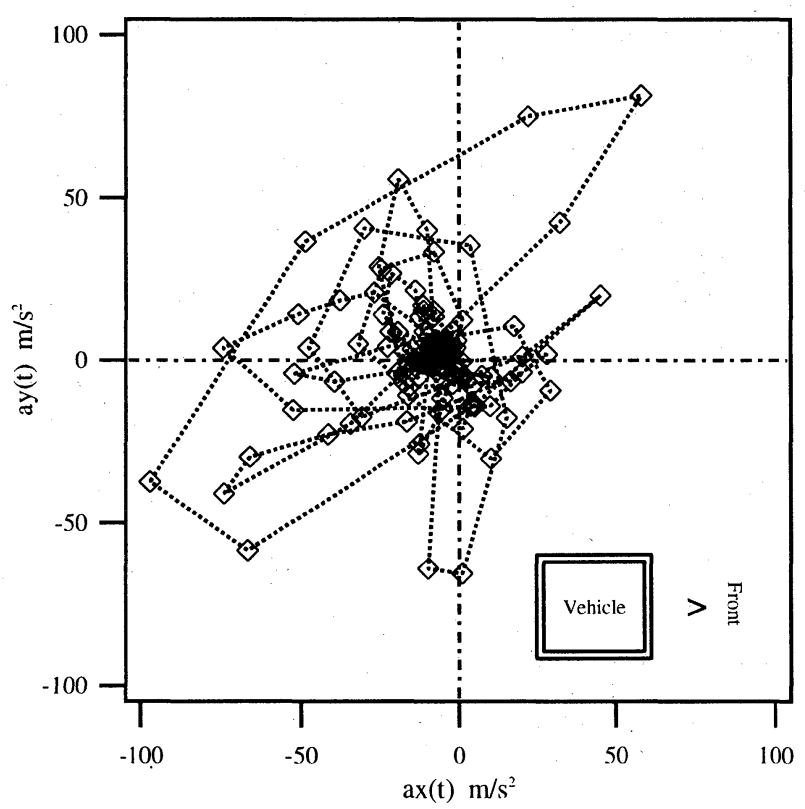

Fig. 6 Time trace of acceleration vector

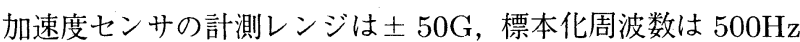
である。

なおここでは事故そのものについては言及しないため， 車両諸元や計測条件などの詳細は割愛する．各軸成分ごとの データを実数として加速度べクトルの大きさと向きに変換 した結果を Fig. 5 に示す。また，加速度べクトルとしての 時間的変化を視覚的に把握するため，ベクトルの時間軌跡を

Fig. 6 に示す

\section{4 解析結果}

Fig. 7 に通常のフーリエ変換によって求めた各軸成分と大 きさと方向に変換した信号の振幅スペクトルを示す．なお， 負の周波数領域は正の領域と対称になるため省略している. そして, Fig. 8 に加速度計測信号を複素表現に変換し複素 フーリエ変換を行なって求めた振幅スペクトルを示す。計算 結果は正負の周波数領域で対称にならないため，周波数軸を 負の領域まで表示している.

これらの計算結果が示すように，どのスペクトルも相似形 にはならず，各々のスペクトルを基に異なる側面から物理的 な挙動を観察することができる。

\section{5 考察}

サンプルデータでは，Fig. 6 から容易に理解されるように 加速度ベクトルが大きさとともに向きも変化しており，平面 上で曲線的軌跡を描くような変化が観察できる。ところが, 各軸成分別に求めたスペクトルや加速度ベクトルの方向変化 のスペクトルだけからその二次元的な挙動の特徵について的 確に言及するのは難しい。 なぜなら，ベクトルが変化する範 囲は Fig. 6 より目安を付けられものの，各軸成分別に求めた スペクトルの相違から二次元的な動き，すなわちその動きの 周期と軌跡の曲がり具合を容易に類推できないからである. これは, 加速度ベクトルの方向変化に関するスペクトルを併 用しても同様である。

一方，複素表現による方法では，3節で示したようにベク トルの二次元的変化を回転運動として捉えることで, Fig. 8 より $80 \mathrm{~Hz}$ 付近を中心とした時計回り運動と反時計回り運動 の合成から加速度ベクトルの時間的変化が成り立っているこ とを容易に把握できる。しかしながら Fig. 8のようにスペク トルデータを羅列したままでは, 個々の加速度デー夕を単純 比較するのには向かない.

そこで，4節で提案した評価関数 $\operatorname{Activity}(T)$, Aspect.r $(T)$, Atitude(T) についてサンプルデータを基に 計算した結果を Fig. 9 に示す．なお，各グラフの横軸は，周 期のオーダーを把握しやすくするために，対数表現とした． こ机らのグラフを基にして加速度べクトルの時間変化に関す る特徵を容易に把握することができる。

まず $\operatorname{Activity}(T)$ のグラフには $14 \mathrm{~ms} \sim 15 \mathrm{~ms}$ 程度の周期で 時計回りの強い回転運動成分が含ま机ていることがめいりょ うに示されている。 また, Activity $(T)$ の積分值は-445で あった。負の值であることから，全体として時計回りの回転 運動の傾向があることを示している。 

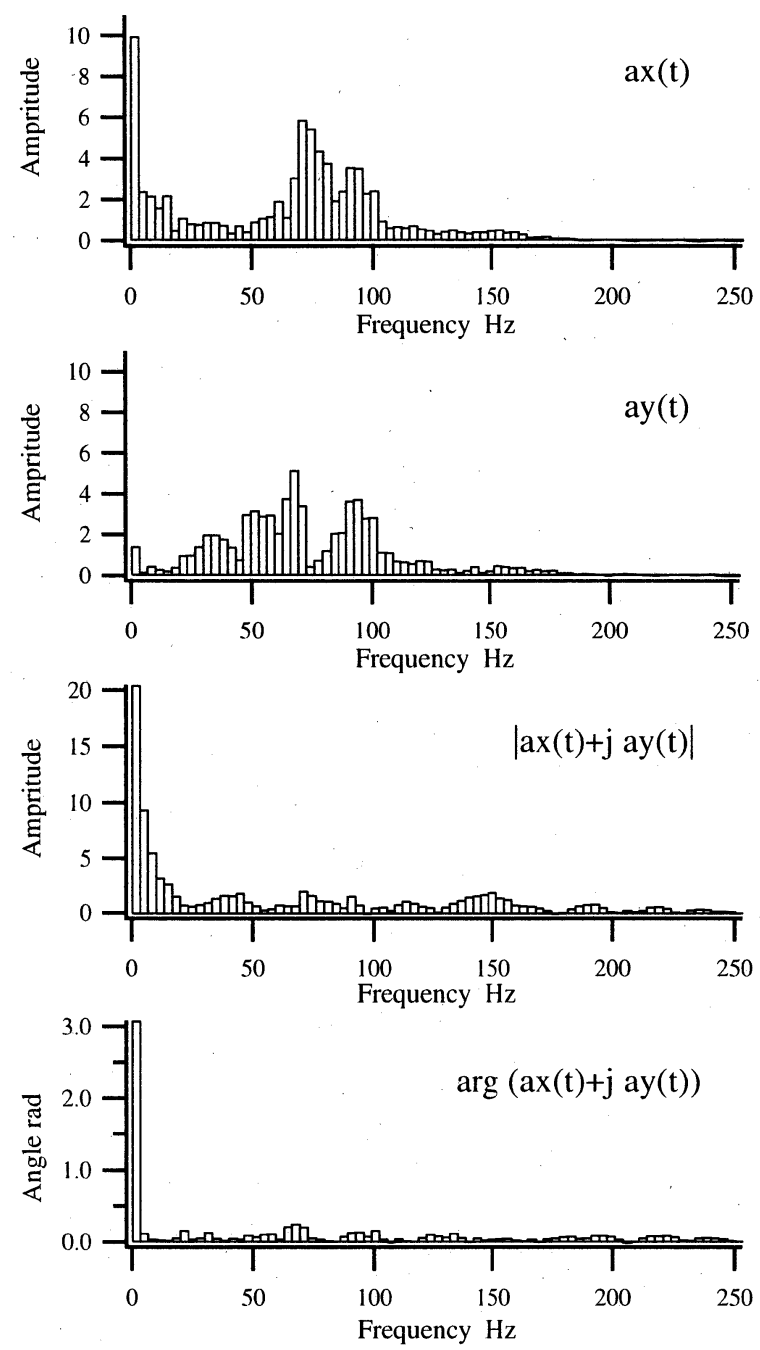

Fig. 7 Comparison of the DFT spectra

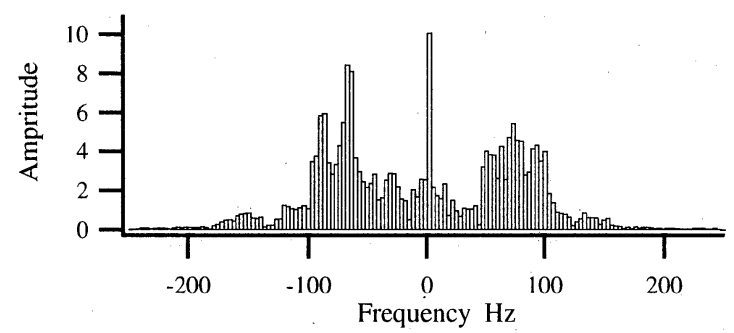

Fig. 8 Result of complex DFT of $c_{a}(t)$

つぎに, Activity(T)のグラフ上でピークを形成している データについて, 対応する Aspect.r $(T)$, Atitude $(T)$ の值を 読みとると, Table 1 となる.こ机らの值から, サンプルデー 夕は, 周期 $14.3 \mathrm{~ms}$ で, $X$ 軸方向に対して左側へ $1.24 \mathrm{rad}($ 約 $71 \mathrm{deg}$ ) 傾いた細長い楕円軌跡を描く運動と周期 $15.0 \mathrm{~ms}$ で, $X$ 軸方向に対して右側へ $1.83 \mathrm{rad}$ (約 $105 \mathrm{deg}$ ) 傾いた長半径と 短半径がほほ $1: 2$ の棈円軌跡を描く運動が主成分であること が推定できる。これを，図形として描いてみると Fig. 10 と なる. 実線の軌跡が周期 $14.3 \mathrm{~ms}$ の運動成分, 破線の軌跡が 周期 $15.0 \mathrm{~ms}$ の運動成分である.こ扎を Fig. 6 と比較すれば その妥当性が理解できる。

また，Fig. 11 に示す別のサンプルデータ 2 個を用いて評
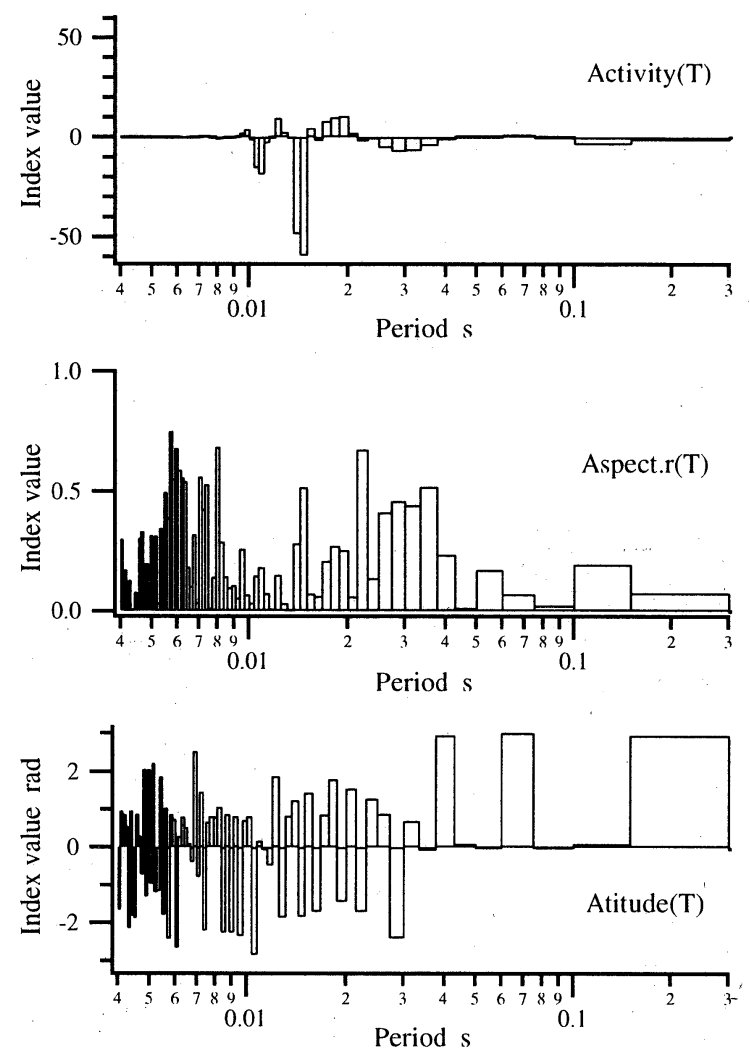

Fig. 9 Results of the evaluation functions

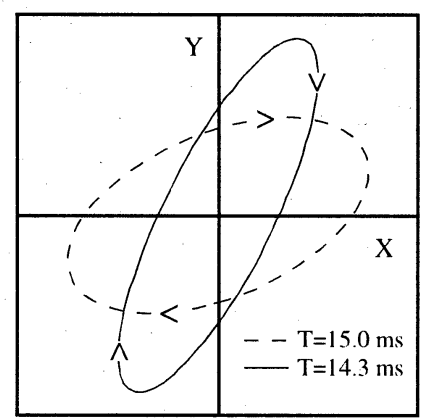

Fig. 10 Trace image of the characteristic peak component 価関数 $\operatorname{Activity}(T)$ を求めた結果を Fig. 12 に示す.このよ うに，おのおの異なる結果が得られることが示された。

複素フーリエ変換によるスペクトル表示は, いわば平面上 のベクトルが作り出す軌跡の曲率変化や形態の特徵を反映し たものとなるため, 加速度の解析・処理だけでなく, 物体の 運動軌跡の自動比較評価や筆跡などの二次元幾何学的なデー 夕の定量的比較にも応用の可能性が考えられる。

加速度解析以外の応用例としては, 署名時における筆記運 動の計測データの解析が考えられる. 筆記時の運動は, 紙上 に残る描画軌跡と筆運びによる描画されない軌跡とからなる. これらを一連の運動として位置計測すれば，二次元の連続し た時系列デー夕となる。このデータに対して本研究による方

Table 1 Values of the characteristic peak

\begin{tabular}{llcl}
\hline Period & Activity $(T)$ & Aspect.r $(T)$ & Atitude $(T)$ \\
\hline $14.3 \mathrm{~ms}$ & -48.9 & 0.28 & 1.24 \\
$15.0 \mathrm{~ms}$ & -59.5 & 0.51 & -1.83 \\
\hline
\end{tabular}



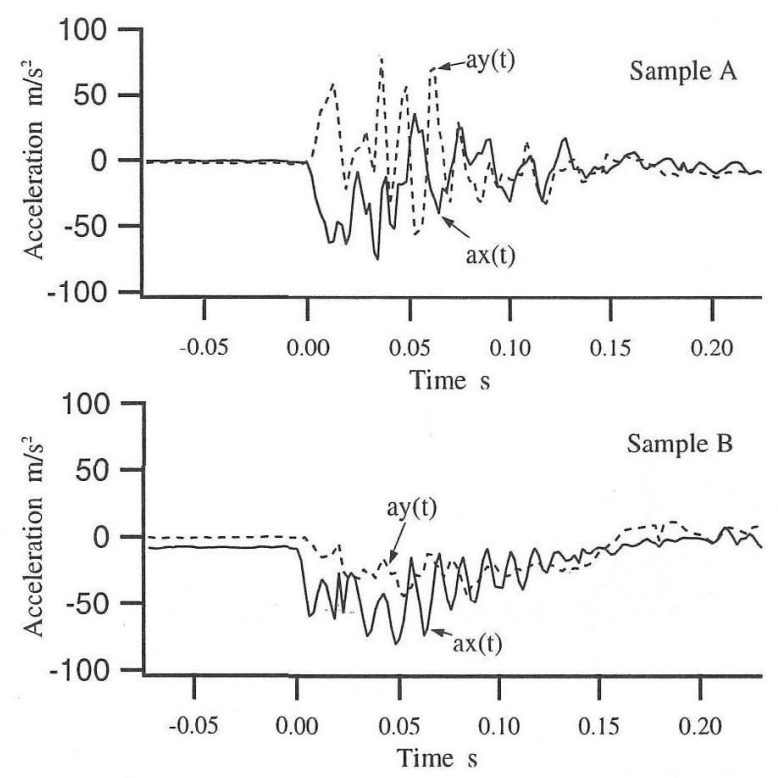

Fig. 11 Other sample signals
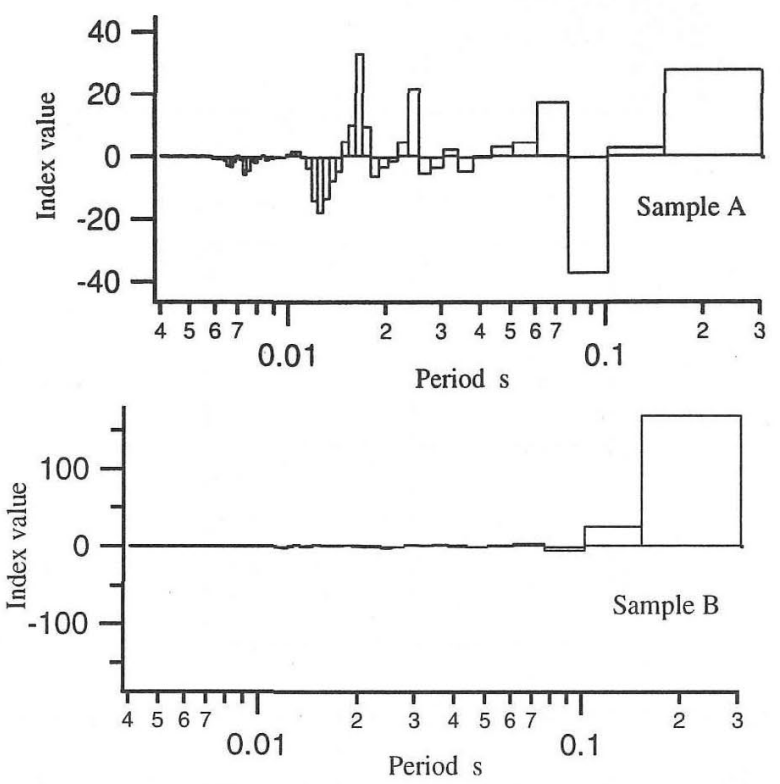

Fig. 12 Results of the evaluation "Activity(T)"

法を適用し，筆記運動の特徵を定量的に評価比較することに よって個人識別への応用が考えられる。

\section{6 補足事項}

今回の解析では虚数軸を車両の横方向に取っているが, 虚 数としての表示は二次元データを一次元的に扱うための便宜 上のものであるため， 2 軸ある計測軸のどちらを虚数表示と するかは本質的な問題ではない. スペクトルなどの解釈時に ベクトルの向きの基準が変化するだけである.

また, 実際に複数デー夕の比較評価を行なう場合には, デー 夕量や標本化周波数の相違を吸収するための処理が必要とな る. なお, デー夕数の多寡による不確定性の問題や, 評価に 必要な周波数分解能などについては, 一般の複素フーリ工解 析に準じるものと考えるが, 個々の応用例について特異的な ことは今後の課題としたい.
6. 結語

加速度の計測面をガウス平面とみなすことによって，二次 元の加速度信号を一つの複素信号として捉えることができる。 これにより加速度信号に対して複素信号処理の各種技法が適 用でき, 複素フーリエ変換によるスペクトル分析が可能とな る.そこで，加速度ベクトルに対する定量的な比較評価への 応用を考え, スペクトル分析を基にした評価関数による解析 方法を提案した。

この方法について，二次元加速度計測信号として自動車の 衝突加速度をサンプルデータに検討を行なったところ, 従来 の方法とは異なる側面でその特徴を観察できることが示され た.すなわち，加速度べクトルの二次元的な動きを定量的に とらえる場合に効果的であると考えられた。

今後は, 具体的な加速度解析への応用とともに，3 自由度 の加速度信号に対する拡張や A D 变換機構に由来する計測 チャンネル間の位相差解消処理などについても研究を進めた い.また, 専用ハードウエアの開発により, 計測信号に対す る実時間処理を実現することにより制御系への組み込みにつ いても検討したい.

\section{参 考 文 献}

1) O. Salomonsson and M. Koch : Crash Recorder for Safety System Studies and as A Consumer's -Product, SAE Technical Paper, 910656, SP-852, 21/33 (1991)

2) H. Norin et al. : Estimating Crash Severity in Frontal Collisions Using the VOLVO Digtal Accident Research Recorder (DARR), Proc. Int. Symp. Automot. Technol. Autom., 94SF24, 409/415 (1994)

3) J. Barth et al. : Der Kienzle UDS - Auswertungen von Referenzunfaellen zur Qualifizierung des Systems, Verkehrsunfall und Fahrzeugtechnik, (1) 23/28 and (2) 32/34 (1994)

1) W. F. Fincham, A. Kast and R. F. Lambourn : The Use of A High Resolution Accident Data Recorder in the Field, SAE Technical Paper, 950351 (1995)

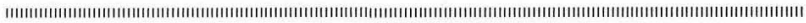

\section{[著 者 紹 介]}

山 本 広 樹 (学生会員)

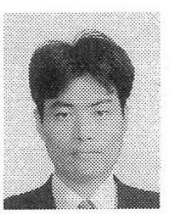
1991 年日本大学理工学部航空宇宙工学科卒業, 特許庁に勤務後, 93 年警察庁科学警察研究所入 所, 法科学第二部機械第一研究室にて機械・交通 関連の事故解析研究と鑑定に従事. 01 年筑波大学 大学院工学研究科入学, 知能機能工学専攻.

青 島 伸 治（正会員）

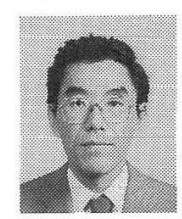

1970 年東京大学工学系研究科応用物理学専門課 程博士課程修了. 同年東京大学宇宙航空研究所助 手. 75 年熊本大学工学部助教授. 79 年筑波大学 物理工学系助教授, 89 年同教授. 99 年同機能工 学系教授. 計測制御工学の教育と研究に従事 (工 学博士). 